(2) Open Access Full Text Article

ORIGINAL RESEARCH

\title{
Leukocyte peroxidase and leptin: an associated link of glycemic tolerance and bronchial asthma?
}

This article was published in the following Dove Press journal:

Diabetes, Metabolic Syndrome and Obesity:Targets and Therapy

8 May 2010

Number of times this article has been viewed

\author{
Sergio Parco \\ Immunopathology Unit, Laboratory \\ of the Department of Medicine, \\ Children's Hospital, IRCCS Burlo \\ Garofolo, Trieste, Italy
}

Correspondence: Sergio Parco Immunopathology Unit, Laboratory of the Department of Medicine, Children's Hospital IRCCS Burlo Garofolo, Trieste, Italy

Email: parco@burlo.trieste.it

\begin{abstract}
Recent observations suggest the presence of an interaction between leptin and the inflammatory system during bronchial asthma. Although there is evidence of a positive association between asthma and obesity in adults and children, little is yet known about the role of serum leptin, as a potential mediator for bronchial epithelial homeostasis, and intraleukocyte myeloperoxidase (MPO), a hemoprotein with a molecular weight of $140 \mathrm{kDa}$, expression of the inflammatory system, in asthmatic children. Glycemic tolerance is an important pathogenetic element in developing type 2 mellitus diabetes and a confirmed predictor of incident asthma-like symptoms in adults. This work is aimed at assessing a possible correlation between basal leukocyte myeloperoxidase levels, basal leptin and insulin-glycemic tolerance in obese children. Thirty obese children aged between 7 and 15 years were examined. The analyzed data showed a normal response to the insulinemic stimulus in children of both sexes whose basal leptin and MPO values, expressed as MPO intracellular index, were within the normal range.
\end{abstract}

Keywords: leptin, myeloperoxidase, glycemic tolerance, asthma

\section{Background}

Recent observations suggest the presence of an interaction between leptin and the inflammatory system during bronchial asthma. ${ }^{1,2}$ Leptin, the hormone mainly synthesized by adipose tissue, is involved in a complex network of neurotrasmitters that modulate appetite. Many tissues produce leptin: the placenta syncytial trophoblast, the gastric fundus mucosa, skeletal muscle tissue and hypophysis. Most of leptin, however, is produced in adipose tissue. Leptin's role is mainly to regulate food intake, but it also has a number of other metabolic functions: it stimulates macrophages and neutrophils, it has an antiapoptotic activity on various cell types, and it regulates T-cell proliferation. The production/suppression of leptin plasma levels is mainly related to the quantity of adipocytes, but also to various endocrinological factors, the main one being insulin levels. The lower the insulin levels, the lower the leptin synthesis. Low insulin levels are in fact typical indicators of hunger. Other factors that stimulate leptin secretion are: adrenergic stimuli, growth hormone $(\mathrm{GH})$ and thyroid hormones such as triiodothyronine and inflammatory stimuli.

The leptin-producing obese (OB) gene is located on chromosome 7 and has three exons and two introns. The OB gene transcription can be regulated by response elements, such as sequences of nucleotides to which transcription factors bind (such as the cAMP Response Element [CRE] $)^{3-5}$ submit your manuscript | www.dovepress.com

Dovepress

8504
Diabetes, Metabolic Syndrome and Obesity:Targets and Therapy 2010:3 I I3-1 I6

(C) 2010 Parco, publisher and licensee Dove Medical Press Ltd. This is an Open Access article which permits unrestricted noncommercial use, provided the original work is properly cited. 
Recent observations suggest the presence of an interaction between leptin and the inflammatory system. However, there is no adequate knowledge about the role of leptin in atopic states, such as bronchial asthma. ${ }^{2}$ Although there is evidence of a positive association between asthma and obesity in adults and children, little is yet known about the role of leptin in asthmatic children: the findings suggest that leptin may play a role in atopic asthma, prevailing in postadolescent male children and in asthmatic boys. Insulin resistance (IR) is a confirmed predictor of incident asthma-like symptoms in adults and leptin is potentially a mediator for bronchial epithelial homeostasis: decreased expression of leptin/leptin receptor characterizes severe asthma and is associated with airway remodelling features. ${ }^{6-9}$

Myeloperoxidase (MPO) is a hemoprotein with a molecular weight of $140 \mathrm{kDa}$, and is made of two light subunits weighing $15 \mathrm{kDa}$. Each MPO molecule contains two porphyrins that play a fundamental role in the catalytic cycle. MPO is firstly found in the grains of neutrophils and eosinophils. It has a bactericidal potential since it catalyzes the production of hypochlorous acid, a potent oxidant generated by the reaction of chloride ion with hydrogen peroxide, which has a significant pro-inflammatory action and contributes directly to tissue damage. The expression of leptin receptors on eosinophils has recently shown that leptin can be considered a survival cytokine for human neutrophils and eosinophils and has a relevant potential role to play in allergic and inflammatory diseases.

\section{Study aim}

This work aims to verify through a retrospective study, the following personal observations: whether the relationship between obesity and asthma are mediated by an inflammatory state as measured by elevated leptin and leukocyte MPO levels in obese children, and by studying glycemic tolerance, which is an early sign of diabetes mellitus and associated IR.

\section{Methods}

Thirty obese children (15 males and 15 females with body mass index $[\mathrm{BMI}]>30$ ), without bronchial asthma symptoms, aged between 7 and 15 years were examined. Informed consent was obtained according to the criteria of the Helsinki Treaty.

Glucose tolerance in these patients was analyzed by providing them with a stimulus: they were administered $1.75 \mathrm{~g}$ of glucose $/ \mathrm{Kg}$ and the response was assessed at times 0 , 60, and $120 \mathrm{~min}$. Leptin was evaluated using ELISA - Technogenetics (Milan, Italy). MPO of neutrophil
Table I Biochemical test values and MPXI values in normal response

\begin{tabular}{lll}
\hline CRP & $0.0 \pm 0.4$ & (n.v. $0.0-0.5 \mathrm{mg} \%)$ \\
fT3 & $3.2 \pm 1.1$ & (n.v. I.62-5.52 pg/mL) \\
fT4 & $1.3 \pm 0-9$ & (n.v. $0.74-2.04 \mathrm{ng} / \mathrm{mL})$ \\
TSH & $2.9 \pm 0.5$ & (n.v. $0.25-4.6 \mathrm{mU} / \mathrm{L})$ \\
Leptin & $7.6 \pm 3.1$ & (n.v. I.64-13.32 mg\%) \\
MPXI & $4 \pm 2.0$ & (n.v. $-10+10)$ \\
\hline
\end{tabular}

Abbreviations: CRP, C-reactive protein; $\mathrm{fT}$, free thyroxine; MPXI, intracellular mean peroxidase index; TSH, thyroid-stimulating hormone.

and eosinophil counts were analyzed with ADVIA 120 automated analyzer as myeloperoxidase intracellular index (MPXI), a parameter derived from the mean position on the axis of an archetypal population of neutrophils and eosinophils: cells absorb light in proportion to the amount of colored peroxidase that is present (reported on $\mathrm{x}$-axis) and spread light in proportion to their size (reported on y-axis). This whole blood automated method is certified and developed to assess eosinophil and neutrophil activity in terms of peroxidase content and cell morphology.

All subjects had an MPXI greater than -10 to ensure that no case of MPO deficiency was included.

The level of C-reactive protein (CRP) as an inflammation index was determined in all the patients and control tests on thyroid functionality, were performed by Modular P1 - Roche (Geneva, Switzerland) to exclude other simultaneous correlated pathologies (Tables 1 and 2). The BMI values for the children aged $7-15$ years were $31.4 \pm 2.7 \mathrm{~kg} / \mathrm{m}$ ?

\section{Results}

The analyzed data showed a normal response to the insulinemic stimulus in children of both sexes whose basal leptin and MPXI values were within the normal range. (Figures 1 and 2). Pathological stimulus-related values were correlated to high basal leptin and MPXI levels

Table 2 Biochemical test and MPXI values in pathological response

\begin{tabular}{lll}
\hline CRP & $0.0 \pm 0.4$ & (n.v. $0.0-0.5 \mathrm{mg} \%)$ \\
fT3 & $2.3 \pm 1.0$ & (n.v. $1.62-5.52 \mathrm{pg} / \mathrm{mL}$ ) \\
fT4 & $1.7 \pm 0.6$ & (n.v. $0.74-2.04 \mathrm{ng} / \mathrm{dL}$ ) \\
TSH & $3.4 \pm 0.6$ & (n.v. $0.25-4.6 \mathrm{mU} / \mathrm{L}$ ) \\
Leptin & $16.3 \pm 4.5$ & (n.v. $1.64-13.32 \mathrm{mg} \%)$ \\
MPXI & $12 \pm 7$ & (n.v. $-10+10)$ \\
\hline
\end{tabular}

Abbreviations: CRP, C-reactive protein; $\mathrm{fT}$, free thyeroxine; MPXI, intracellular mean peroxidase index; TSH, thyroid-stimulating hormone. 
(Figures 3 and 4). MPXI and leptin are directly correlated one with the other $(P<0.001)$. The CRP results and other main thyroid tests were in the normal range.

\section{Discussion}

MPXI for subjects of the same group of age, without asthma symptoms, but with obesity and normal range of basal glucose, are defined in the literature. ${ }^{16,17}$

Many evidences show a correlation between obesity and increased risk of bronchial asthma. Altered GT and IR are believed to play an significant role in asthma, although precise data are not available. ${ }^{10-15} \mathrm{IR}$ is, after all, a common condition in many multifactorial diseases such as obesity and type 2 diabetes. The presence of a common inflammatory factor may explain the relationship between GT, IR, and asthma. Leptin is known to be one of these factors. A high MPXI could be another contributing factor that may have to be assessed when directly correlated with leptin. Our experience has shown that high MPO and leptin levels are indicative of an altered response to the glucose and IR load.

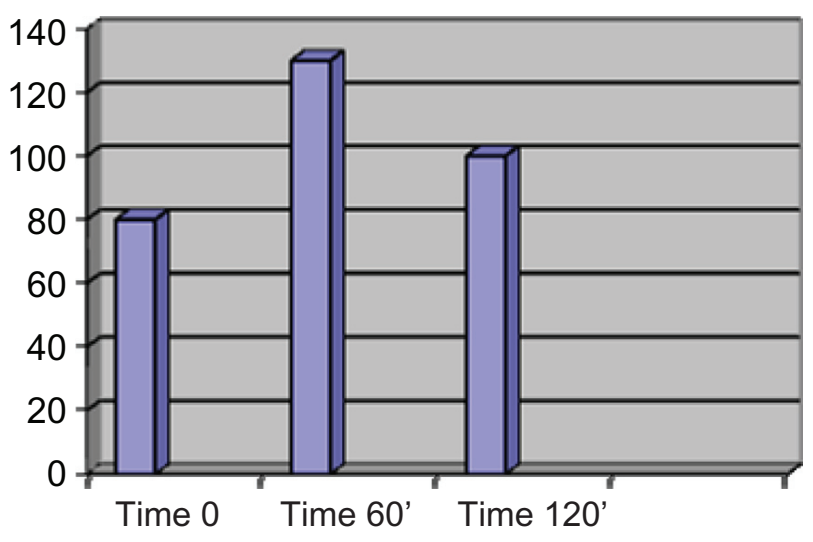

Figure I Glucose $(\mathrm{mg} \%)$ and insulin levels $(\mu \mathrm{Ul} / \mathrm{mL})$ after oral glucose tolerance test in normal response.

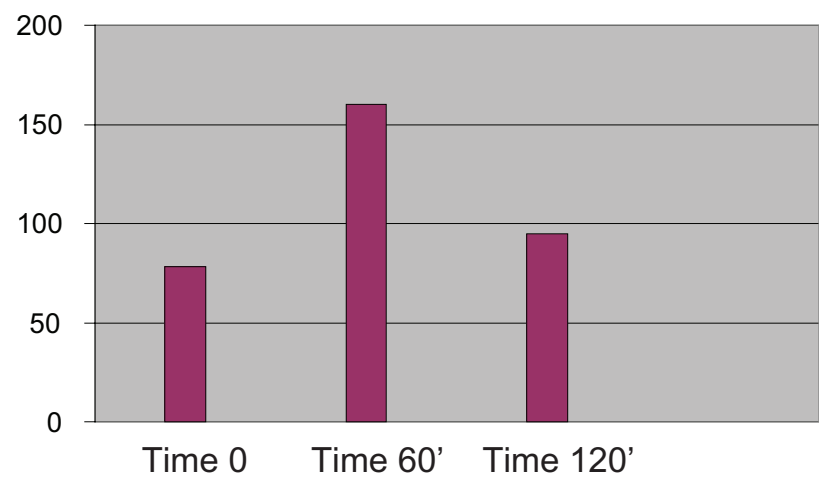

Figure 2 Insulin levels $(\mu \mathrm{Ul} / \mathrm{mL})$ after oral glucose tolerance test in normal response.

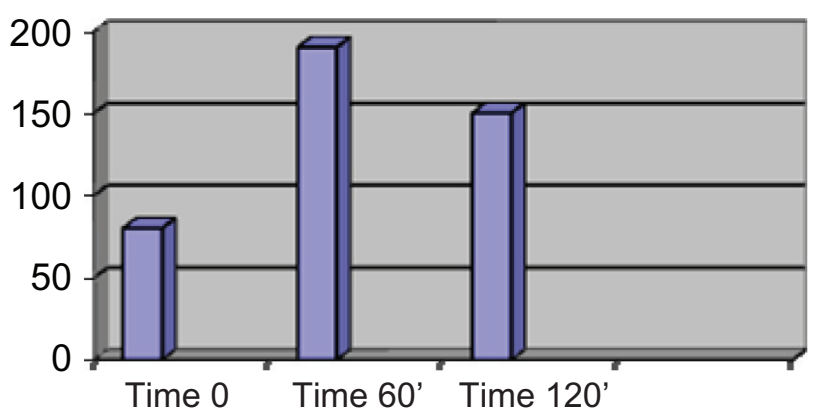

Figure 3 Glucose (mg\%) after oral glucose tolerance test in pathological response.

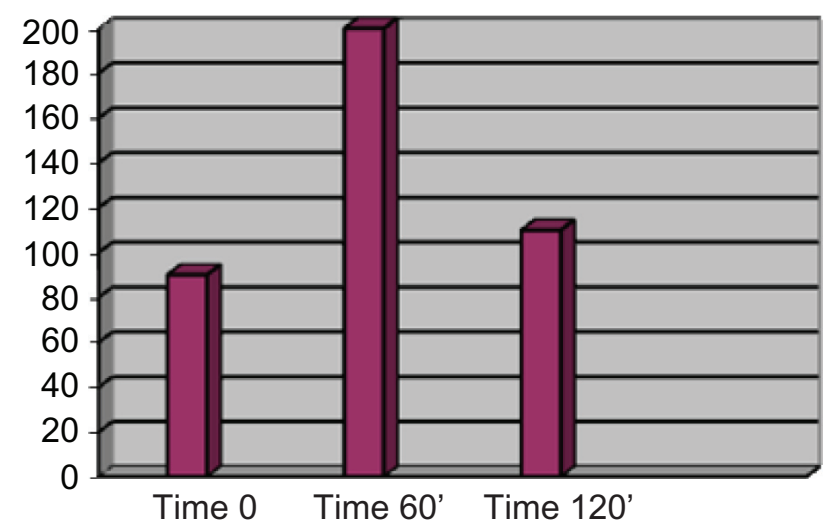

Figure 4 Insulin levels $(\mu \mathrm{Ul} / \mathrm{mL})$ after oral glucose tolerance test in pathological response.

Our work is aimed at proposing the determination of leukocyte MPXI when analyzing basal leptin and serum glucose. This test is included in the hemochrome-cytometric exam and does not entail any extra costs. Associated high levels of MPXI and leptin in obese children may suggest an altered response to the oral glucose load and to be prediction of asthma.

\section{Acknowledgment}

The author expresses his thanks to Mrs Sarah Tripepi for her work. The author reports no conflicts of interest in this work.

\section{References}

1. Bruno A, Pace E, Chanez P, et al. Leptin and receptor expression in asthma. J Allergy Clin Immunol. 2009;124:230-237.

2. Guler N, Kirerleri E, Ones U, et al. Leptin: does it have any role in childhood asthma? J Allergy Clin Immunol. 2004;114:254-259.

3. Frühbeck G, Gómez-Ambrosi J, Muruzábal FJ, Burrell MA. The adipocyte: a model for integration of endocrine and metabolic signaling in energy metabolism regulation. Am J Physiol Endocrinol Metab. 2001;280:E827-847.

4. Fasshauer M, and Paschke R. Regulation of adypocytokines and insulin resistance. Diabetologia. 2003;46:1594-1603.

5. Lyon CJ, Law RE, Hsueh WA. Mini review: adiposity, inflammation, and atherogenesis. Endocrinology. 2003;144:2195-2200.

6. Gabriely I, and Barzilai N. The role of fat cell derived peptides in age-related metabolic alterations. Mech Ageing Dev. 2001;122: $1565-1576$. 
7. Zamboni M, Zoico E, Fantin F, et al. Relation between leptin and the metabolic syndrome in elderly women. J Gerontol A Biol Sci Med Sci. 2004;59:396-400.

8. Zoico E, Di Francesco V, Mazzali G, et al. Adipocytokines, fat distribution and insulin resistance in elderly men and women. J Gerontol A Biol Sci Med Sci. 2004;59:M935-939.

9. Armellini F, Robbi R, Zamboni M, et al. Resting metabolic rate, body-fat distribution and visceral fat in obese women. Am J Clin Nutr. 1992;56:981-987.

10. Zamboni M, Armellini F, Cominacini L, et al. Obesity and regional body-fat distribution in men: separate and joint relationships to glucose tolerance and plasma lipoproteins. Am J Clin Nutr. 1994;60:682-687.

11. Zamboni M, Armellini F, Harris T, et al. Effects of age on body fat distribution and cardiovascular risk factors in women. Am J Clin Nutr. 1997;66:111-115.

12. Lefebre AM, Laville M, Vega N, et al. Depot-specific differences in adipose tissue gene expression in lean and obese subjects. Diabetes. 1998; 47:98-103.

13. Boden G, Chen X, Ruiz J, et al. Mechanisms of fatty acid-induced inhibition of glucose uptake. J Clin Invest. 1994;93:2438-2446.
14. Kern PA, Saghizadeh M, Ong JM, et al. The expression of tumor necrosis factor in human adipose tissue. Regulation by obesity, weight loss, and relationship to lipoprotein lipase. J Clin Invest. 1995;95: 2111-2119.

15. Jequiér E. Long-term measurement of energy expenditure in men: direct or indirect calorimetry? In: Bjorntorp P, Cairella M, Howard AN, editors. Recent Advances in Obesity Research III. London, UK: John Libbey and Company Publ; 1981:130-135.

16. Leckie MJ, Bryan SA, Khan J, et al. Automated quantitation of circulating neutrophil and eosinophil activation in asthmatic patients. Thorax. 2000;55:471-477.

17. Fujisawa T, Terada A, Atsuta J, et al. Clinical utility of serum levels of eosinophil cationic protein (BCP) for monitoring and predicting clinical course in children asthma. Clin Exp Allergy. 1998;28:19-25.

18. Diez JJ, Iglesias P. The role of the novel adipocyte-derived hormone adiponectin in human disease. Eur J Endocrinol. 2003;148: 293-300.

\section{Publish your work in this journal}

Diabetes, Metabolic Syndrome and Obesity: Targets and Therapy is an international, peer-reviewed open-access journal committed to the rapid publication of the latest laboratory and clinical findings in the fields of diabetes, metabolic syndrome and obesity research. Original research, review, case reports, hypothesis formation, expert opinion and commentaries are all considered for publication. The manuscript management system is completely online and includes a very quick and fair peer-review system, which is all easy to use. Visit http://www.dovepress.com/testimonials.php to read real quotes from published authors. 